\title{
Waktu dan Dosis Aplikasi Kalsium dan Boron untuk Pengendalian Getah Kuning pada Buah Manggis (Garcinia mangostana L.) di Tiga Sentra Produksi
}

\author{
Time and Application Dosage of Calcium and Boron for Yellow Sap Controlling on \\ Mangosteen Fruit (Garcicnia mangostana L.) in Three Production Centres
}

\author{
Vandra Kurniawan ${ }^{1}$, Roedhy Poerwanto ${ }^{1^{*}}$, dan Darda Efendi ${ }^{1}$
}

Diterima 21 Januari 2016/Disetujui 16 Maret 2016

\begin{abstract}
Contamination of yellow sap $(G K)$ in the mangosteen fruit leads to low quality of the mangosteen fruit. GK contamination occurs because the cell walls of the fruit is weak due to lack of calcium (Ca) and boron (B). Ca and B plays a role in maintaining the integrity of the cell wall. The study aimed to get the best treatment of dose and the time of application of $C a$ and $B$ in controlling the contamination of GK on the aryl and mangosteen pericarp. This study used a nested design with 3 factors. First factor was study site, consisting of Cigudeg, Citeureup and Cikembar. The second factor was combination dose of fertilizer, consisting of control (without $\mathrm{Ca}+\mathrm{B}), 1.6 \mathrm{~kg} \mathrm{Ca}$ tree $\mathrm{e}^{-1}+$ $1.553 \mathrm{~g} \mathrm{~B}$ tree $^{-1}$, and $3.2 \mathrm{~kg}$ of Ca tree ${ }^{-1}+1.553 \mathrm{~g} \mathrm{~B}$ tree $^{-1}$. The third factor was time of fertilizer application, consisting of anthesis, stadia 1, and anthesis + stadia lof fruit development. Result of the study showed that location which produced the best fruit was Cikembar where GK on aryl was $22.49 \%$ and on pericarp was $29.51 \%$. A dose of $1.6 \mathrm{~kg} \mathrm{Ca} \mathrm{tree} e^{-1}+1.55 \mathrm{~g} \mathrm{~B}$ tree $e^{-1}$ and $3.2 \mathrm{~kg} \mathrm{Ca}$ tree ${ }^{1}+1.55 \mathrm{~g} \mathrm{~B}$ tree ${ }^{-1}$ were equally well in reducing GK contamination In aryl (19.91\%) and pericarp (28.86\%) compared to treatment without $C a$ and $B$ which showed percentage of GK contaminated fruit on aryl was $50.00 \%$ and on pericarp was $56.46 \%$. Ca and B application time was the best at stage 1, which lowered the percentage of GK contamination in aryl $(40.44 \%)$ and pericarp (27.10\%). Ca and B did not affect the physicochemical qualities including diameter, weight, hardness, total soluble solid, total titratable acidity of mangosteen fruit in three study sites.
\end{abstract}

Keywords: fertilization, immobile nutrient, cell wall, pericarp, yellow sap.

\section{ABSTRAK}

Cemaran getah kuning (GK) pada buah manggis menyebabkan rendahnya mutu buah manggis. Cemaran GK terjadi karena dinding sel buah lemah akibat kekurangan unsur kalsium (Ca) dan boron (B). Ca dan B berperan dalam menjaga integritas dinding sel. Penelitian bertujuan untuk mendapatkan dosis dan waktu aplikasi Ca dan B yang terbaik dalam mengendalikan cemaran GK pada aril dan kulit buah manggis. Penelitian ini menggunakan Rancangan Tersarang (Nested Design) 3 faktor. Faktor ke-1 adalah lokasi penelitian, terdiri dari Cigudeg, Citeureup dan Cikembar. Faktor ke-2 adalah kombinasi dosis pupuk yaitu kontrol (tanpa $\mathrm{Ca}+\mathrm{B}$ ), $1.6 \mathrm{~kg} \mathrm{Ca}$ pohon $^{-1}+1.553 \mathrm{~g} \mathrm{~B}$ pohon $^{-1}$, dan $3.2 \mathrm{~kg} \mathrm{Ca}$ pohon $^{-1}+1.553 \mathrm{~g} \mathrm{~B}$ pohon $^{-1}$. Faktor ke-3 adalah waktu aplikasi pupuk yaitu pada saar antesis, Stadia 1, dan Antesis + Stadia 1 dari perkembangan buah. Hasil penelitian menunjukkan bahwa lokasi penelitian dengan kualitas fisik buah terbaik adalah di Cikembar dengan persentase cemaran GK pada aril $(22.49 \%)$ dan kulit $(29.51 \%)$. Dosis $1.6 \mathrm{~kg} \mathrm{Ca}$ pohon $^{-1}+1.55 \mathrm{~g} \mathrm{~B}$

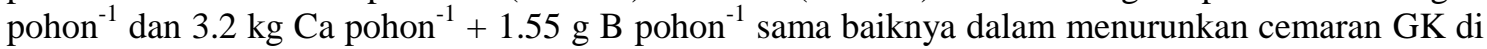
aril (19.91\%) dan di kulit (28.86\%) dibandingkan dengan perlakuan tanpa Ca dan B menunjukkan persentase buah tercemar GK pada aril (50.00\%) dan kulit (56.46\%). Waktu aplikasi Ca dan B yang terbaik adalah pada stadia 1 yang menurunkan persentase cemaran GK di aril (40.44\%) dan kulit

${ }^{1}$ Departemen Agronomi dan Hortikultura, Fakultas Pertanian, Institut Pertanian Bogor (Bogor Agricultural University), J1. Meranti Kampus Darmaga, Bogor 16680 Indonesia. Telp/ Faks. 62-251-8629353.

email: roedhy8@yahoo.co.id. (*penulis korespondensi) 
(27.10\%). Ca dan B tidak mempengaruhi kualitas fisikokimia yang mencakup diameter, bobot, kekerasan, padatan terlarut total, asam tertitrasi total buah manggis di tiga lokasi penelitian.

Kata kunci: pemupukan, hara tidak mobil, dinding sel, pericap, getah kuning.

\section{PENDAHULUAN}

Manggis (Garcinia mangostana L.) merupakan salah satu komoditas hortikultura andalan Indonesia, baik untuk pasar domestik maupun internasional. Volume ekspor manggis Indonesia meningkat dari 10100 ton pada tahun 2010 menjadi 20169 ton pada tahun 2012, namun mengalami penurunan menjadi 7647 ton pada tahun 2013 karena ketersediaan produk bermutu yang memenuhi standar ekspor masih rendah (PKBT, 2007). Persyaratan mutu buah untuk tujuan ekspor kelas super adalah kulit buah mulus tidak mengalami cacat biologis maupun cacat mekanis seperti burik dan getah kuning (BSN, 2009).

Getah kuning adalah getah yang dihasilkan secara alami pada setiap organ manggis. Getah kuning pada dasarnya diproduksi oleh tanaman untuk keperluan metabolisme dan sistem pertahanan tanaman. Saluran getah kuning terdapat pada semua jaringan tanaman manggis. Struktur sekretori getah kuning pada buah manggis berbentuk saluran memanjang dan bercabang, dikelilingi oleh sel-sel epithelium. Getah kuning menjadi masalah ketika keluar dari saluran getah kuning yang pecah dan mengotori aril (daging buah) atau kulit buah (pericarp) manggis (Dorly et al., 2008).

Pecahnya saluran getah kuning dapat disebabkan oleh perbedaan laju pertumbuhan antara biji dan aril dengan pericarp selama fase pembesaran buah yang menimbulkan desakan mekanik dari biji dan aril ke pericarp (Poerwanto et al., 2010). Selain itu juga, perubahan potensial air tanah yang terjadi secara tiba-tiba menyebabkan adanya tekanan turgor pada dinding sel epitel, baik dari dalam (turgor plasma sel), maupun dari luar (turgor cairan getah). Apabila dinding sel epitel lemah akibat kekurangan $\mathrm{Ca}$, maka sel-sel akan mudah pecah dan mengeluarkan getah kuning.

$\mathrm{Ca}$ menjadi substansi perekat pada struktur dinding sel dalam bentuk Ca-pektat yang mengikat rantai pektin (Marschner, 1995; Huang et al., 2005). Ca merupakan unsur hara makro bersifat tidak mobil karena tidak dapat didistribusikan kembali ke jaringan yang lebih muda sehingga daun muda dan buah yang sedang berkembang secara penuh bergantung pada pengiriman $\mathrm{Ca}$ dalam aliran transpirasi dari xylem (Bangerth, 1979; Marschner, 1995; Saure, 2005).

Beberapa penelitian mengenai aplikasi $\mathrm{Ca}$ telah dilakukan untuk mencegah cemaran getah kuning dan meningkatkan kandungan $\mathrm{Ca}$ pada eksokarp, namun demikian aplikasi $\mathrm{Ca}$ yang dilakukan pada kondisi dan saat yang tidak tepat ternyata tidak efektif. Pemupukan Ca pada saat menjelang berbunga tidak dapat meningkatkan kandungan $\mathrm{Ca}$ buah, tetapi meningkatkan kandungan $\mathrm{Ca}$ pada daun (Dorly, 2009). Aplikasi Ca pada saat antesis menjadi penting untuk mendapatkan pengaruh optimum dalam mengurangi getah kuning pada buah, karena merupakan awal perkembangan buah (Poovarodom, 2009). Depari (2011) menyatakan waktu aplikasi Ca saat akhir stadia 1 yaitu 1-4 Minggu Setelah Antesis (MSA) berpengaruh nyata menurunkan cemaran getah kuning pada aril dan kulit buah manggis dengan meningkatnya kandungan $\mathrm{Ca}$ pada endokarp. Hasil penelitian Wulandari dan Poerwanto (2010) menunjukkan bahwa aplikasi dosis 3.5 ton $\mathrm{Ca}^{2+} \mathrm{ha}^{-1}$ dapat menurunkan getah kuning pada kulit manggis tetapi tidak pada bagian aril manggis.

Hasil penelitian Primilestari (2011) aplikasi $\mathrm{Ca}$ dengan sumber kapur dolomit lebih efektif dalam mencegah cemaran getah kuning pada aril dan kulit buah manggis dibandingkan Ca dengan sumber kaptan. Hasil penelitian Dorly (2009) menggunakan pupuk Ca sebanyak 6 ton $\mathrm{Ca}^{2+}$ ha tahun ${ }^{-1}$, Depari (2011) sebanyak 3.5 ton $\mathrm{Ca}^{2+}$ ha tahun ${ }^{-1}$, Purnama (2014) sebanyak 3.125 ton $\mathrm{Ca}^{2+}$ ha $\operatorname{tahun}^{-1}$, namun dosis pupuk Ca tersebut masih tergolong tinggi sehingga menyebabkan biaya produksi menjadi tinggi. Untuk mengurangi penggunaan dosis pupuk $\mathrm{Ca}$ maka diperlukan penelitian lanjutan mengenai aplikasi dosis pupuk $\mathrm{Ca}$ pada berbagai sentra produksi manggis yang memiliki masalah cemaran getah kuning. 
Unsur lain yang memiliki fungsi dalam menjaga integritas dinding sel adalah boron (B). Boron berfungsi dalam pembelahan dan pembesaran sel selama fase pertumbuhan (Dear dan Weir, 2004). Marschner (1995); Blevins dan Lukaszewski (1998); dan O’Neill et al. (2004) menyatakan bahwa B menjadi bagian dari komponen struktural sel dan berperan meningkatkan stabilitas dan ketegaran sturuktur dinding sel dan integritas membran plasma. Ikatan B terhadap pektin akan mendukung fungsi $\mathrm{Ca}$ dalam meningkatkan kekuatan dinding sel, khususnya dinding selsel epitel penyusun saluran getah kuning. Oleh karena itu, Ca dan B akan meningkatkan ketahanan saluran getah kuning buah manggis terhadap resiko terjadinya pecah pada saat terjadi tekanan terhadap saluran tersebut. Aplikasi Ca dan B pada buah manggis mampu meningkatkan kandungan $\mathrm{Ca}$ pada pericarp dan menurunkan potensi cemaran getah kuning (Pechkeo et al., 2007).

Kombinasi pupuk $\mathrm{Ca}$ dan $\mathrm{B}$ dapat mengendalikan cemaran kuning pada buah manggis. Menurut Poerwanto et al. (2010) Ca dan B tanah, serta kandungan $\mathrm{Ca}$ dan $\mathrm{B}$ jaringan berkontribusi menekan insiden getah kuning buah manggis. Poovarodom (2010) melaporkan bahwa aplikasi Ca melalui tanah menjadi lebih efektif bila dikombinasikan dengan aplikasi B. Saribu (2011) menyatakan bahwa aplikasi $5.79 \mathrm{~kg} \mathrm{Ca}$ pohon ${ }^{-1}$ tahun $^{-1}$ melalui tanah $+1.553 \mathrm{~g} \mathrm{~B}$ pohon ${ }^{-1}$ tahun $^{-1}$ dapat menurunkan cemaran getah kuning pada aril buah, skor getah kuning pada aril, dan meningkatkan kandungan B di endokarp buah manggis.

Penelitian ini bertujuan untuk (1) mendapatkan dosis $\mathrm{Ca}$ dan $\mathrm{B}$ yang terbaik dalam mengendalikan cemaran getah kuning pada aril dan kulit buah manggis, (2) mendapatkan waktu aplikasi Ca dan B yang terbaik dalam mengendalikan cemaran getah kuning pada aril dan kulit buah manggis.

\section{BAHAN DAN METODE}

Penelitian dilaksanakan di kebun manggis Desa Wargajaya, Kecamatan Cigudeg dan Desa Leuwikaret, Kecamatan Citeureup di Kabupaten Bogor, serta di Desa Bojongkembar, Kecamatan Cikembar di Kabupaten Sukabumi mulai bulan November 2014 sampai April
2015. Pengamatan cemaran getah serta sifat fisik dan kimia buah dilakukan di Laboratorium Pascapanen Departemen Agronomi dan Hortikultura, Institut Pertanian Bogor.

Penelitian ini menggunakan Rancangan Tersarang (Nested Design) 3 faktor. Faktor ke1 adalah lokasi penelitian yang berbeda yaitu Citeurup, Cigudeg dan Cikembar. Faktor ke-2 adalah dosis pupuk $\mathrm{Ca}$ dan $\mathrm{B}$ yaitu: kontrol (tanpa Ca dan B), $1.6 \mathrm{~kg} \mathrm{Ca}$ pohon $^{-1}(5.33 \mathrm{~kg}$ dolomit pohon $\left.^{-1}\right)+1.553 \mathrm{~g} \mathrm{~B}^{-1}$ pohon $^{-1}(3.2 \mathrm{~g}$ finbor pohon $\left.{ }^{-1}\right), 3.2 \mathrm{~kg} \mathrm{Ca}$ pohon $^{-1}(10.67 \mathrm{~kg}$ dolomit pohon $\left.{ }^{-1}\right)+1.553 \mathrm{~g} \mathrm{~B}^{-1}$ pohon $^{-1}(3.2 \mathrm{~g}$ finbor pohon $\left.{ }^{-1}\right)$. Faktor ke-3 adalah waktu aplikasi Ca dan B yang terdiri dari saat antesis (80\% dari populasi telah antesis), stadia 1 (2 minggu setelah antesis), dan antesis + stadia 1 . Perlakuan 3 faktor tersebut diulang 4 kali, sehingga total tanaman manggis yang digunakan adalah 108 tanaman. Data dianalisis menggunakan analisis ragam, untuk hasil yang berbeda nyata dilakukan uji lanjut Duncan Multiple Range Test (DMRT) pada taraf 5\%.

Pohon manggis yang digunakan dalam penelitian ini adalah pohon yang berada pada fase pembungaan (antesis). Persiapan tanaman dilakukan dengan memilih dan mengelompokkan tanaman manggis berdasarkan bentuk yang relatif seragam. Pengacakan dilakukan pada setiap kelompok. Pelabelan dilakukan pada saat antesis untuk menentukan buah yang akan dijadikan sampel untuk pengamatan. Sumber $\mathrm{Ca}$ yang digunakan adalah pupuk dolomit $\left(\mathrm{CaMg}\left(\mathrm{CO}_{3}\right)_{2}\right)$ yang memiliki kandungan $\mathrm{CaO}$ sebesar 30\%. Aplikasi dolomit dilakukan dengan cara ditabur dalam larikan yang dibuat pada sekeliling pohon manggis di bawah tajuk tanaman lalu ditutup kembali dengan tanah. Sumber B berasal dari finbor $\left(48 \% \quad \mathrm{~B}_{2} \mathrm{O}_{3}\right)$. Aplikasi finbor dilakukan dengan cara dilarutkan dalam air kemudian disiramkan di bawah tajuk tanaman. Pemanenan buah manggis dilakukan pada umur 105-114 hari setelah antesis ( HSA).

Komponen yang diamati pada percobaan ini terdiri atas 2 bagian, yaitu pengamatan kualitatif dan kuantitatif. Pengamatan kualitatif dilakukan untuk mengukur tingkat cemaran getah kuning pada buah manggis, baik pada kulit bagian luar, maupun pada bagian dalam atau aril buah. Terdapat 3 komponen kualitatif yang diamati yaitu persentase buah yang kulitnya tercemar getah kuning yang dihitung menggunakan 
rumus persentase jumlah buah yang kulitnya tercemar getah kuning dibagi total buah yang diamati. Persentase aril tercemar getah kuning dihitung menggunakan rumus jumlah buah yang arilnya tercemar getah kuning dibagi total buah yang diamati. Persentase juring tercemar getah kuning dihitung menggunakan rumus jumlah juring yang tercemar getah kuning dibagi jumlah aril yang diamati.

Pengamatan kuantitatif dilakukan untuk melihat pengaruh pemupukan terhadap kondisi fisik dan kimia buah. Komponen yang diamati yaitu diameter horizontal (transversal) dan vertikal (longitudinal) buah, serta tebal kulit yang menggunakan jangka sorong. Bobot buah, bobot aril, bobot cupat, bobot kulit dan bobot biji yang ditimbang menggunakan timbangan digital. Edible portion yang dihitung menggunakan rumus persentase bobot buah yang dimakan dibagi dengan bobot buah total. Kekerasan kulit buah yang diukur dengan penetrometer dan padatan terlarut total (PTT) yang diukur menggunakan hand refractometer. Asam tertitrasi total (ATT) yang diukur melalui metode titrasi dengan menggunakan larutan $\mathrm{NaOH} 0.1 \mathrm{~N}$, indikator phenolphtalein (PP), dan akuades. Skor rasa buah dengan metode skoring yang telah dilakukan Suyanti et al. (1999) yaitu 5 = sangat manis, $4=$ manis, 3 $=$ manis sedikit asam, $2=$ asam agak dominan dari manis, 1 = asam sangat dominan dari manis. Skor rasa buah didapat dari skor rata-rata yang dihasilkan 3 orang penguji rasa.

\section{HASIL DAN PEMBAHASAN}

\section{Cemaran Getah Kuning pada Aril dan Kulit Buah Manggis}

Perbedaan lokasi memberikan pengaruh yang berbeda nyata terhadap persentase aril, juring dan kulit bergetah kuning pada buah manggis (Tabel 1). Persentase aril tercemar getah kuning nyata tertinggi pada perlakuan tanpa pemberian pupuk $\mathrm{Ca}$ dan $\mathrm{B}$ (Tabel 1). Dosis Ca dan B $1.6 \mathrm{~kg} \mathrm{Ca}^{2+}$ pohon $^{-1}+1.55 \mathrm{~g} \mathrm{~B}$ pohon $^{-1}$ menunjukkan hasil yang sama baiknya dalam menurunkan cemaran getah kuning dengan perlakuan $3.2 \mathrm{~kg} \mathrm{Ca}^{2+}$ pohon $^{-1}+1.55 \mathrm{~g}$ B pohon ${ }^{-1}$. Aplikasi Ca $1.6 \mathrm{~kg} \mathrm{Ca}^{2+}$ pohon $^{-1}$ atau setara dengan 1 ton $\mathrm{Ca}^{2+}$ ha $^{-1}$ telah mencukupi untuk menurunkan persentase cemaran getah kuning pada aril dan juring buah manggis dari 50\% menjadi $19.91 \%$ (Tabel 1).

Aplikasi Ca dan B pada saat stadia 1 memiliki persentase cemaran getah kuning paling rendah baik di aril maupun juring buah manggis yakni masing-masing $21.18 \%$ dan $11.93 \%$. Dengan demikian aplikasi pupuk $\mathrm{Ca}$ pada stadia 1 mampu menurunkan persentasi cemaran getah kuning di aril $40.44 \%$ dan pada juring $34.95 \%$. Persentase aril tercemar getah kuning tertinggi yaitu saat antesis, namun tidak berbeda nyata dengan aplikasi pada saat antesis + stadia 1 (Tabel 1).

Tabel 1. Pengaruh lokasi, dosis Ca dan B dan waktu aplikasi terhadap persentase cemaran getah kuning pada aril, juring dan kulit buah manggis.

\begin{tabular}{|c|c|c|c|}
\hline Perlakuan & $\begin{array}{c}\text { Persentase Aril } \\
\text { Tercemar }(\%)\end{array}$ & $\begin{array}{c}\text { Persentase Juring } \\
\text { Tercemar Per Buah }(\%)\end{array}$ & $\begin{array}{c}\text { Persentase Kulit } \\
\text { Tercemar }(\%) \\
\end{array}$ \\
\hline \multicolumn{4}{|l|}{ Lokasi } \\
\hline Cigudeg & $33.47 \mathrm{a}$ & $18.19 \mathrm{a}$ & $44.58 \mathrm{a}$ \\
\hline Citeureup & $35.49 \mathrm{a}$ & $16.60 \mathrm{a}$ & $42.47 \mathrm{a}$ \\
\hline Cikembar & $22.49 \mathrm{~b}$ & $10.48 \mathrm{~b}$ & $29.51 b$ \\
\hline \multicolumn{4}{|l|}{ Dosis $\mathrm{Ca}+\mathrm{B}$} \\
\hline 0 & $50.00 \mathrm{a}$ & $25.79 \mathrm{a}$ & $56.46 \mathrm{a}$ \\
\hline $1.6 \mathrm{~kg} \mathrm{Ca}+1.55 \mathrm{~kg} \mathrm{~B}_{\text {pohon }}{ }^{-1}$ & $19.91 b$ & $8.54 \mathrm{~b}$ & $31.25 \mathrm{~b}$ \\
\hline $3.2 \mathrm{~kg} \mathrm{Ca}+1.55 \mathrm{~kg} \mathrm{~B}$ pohon $^{-1}$ & $21.54 \mathrm{~b}$ & $10.94 \mathrm{~b}$ & $28.86 \mathrm{~b}$ \\
\hline \multicolumn{4}{|l|}{ Waktu Aplikasi } \\
\hline Antesis & $35.56 \mathrm{a}$ & $15.00 \mathrm{ab}$ & $44.10 \mathrm{a}$ \\
\hline Stadia 1 & $21.18 \mathrm{~b}$ & $11.93 b$ & $32.15 b$ \\
\hline Antesis + Stadia 1 & $34.71 \mathrm{a}$ & $18.34 \mathrm{a}$ & $40.32 \mathrm{ab}$ \\
\hline Interaksi & tn & tn & tn \\
\hline
\end{tabular}


Aplikasi pupuk $\mathrm{Ca}$ dan $\mathrm{B}$ juga memberikan pengaruh yang berbeda nyata terhadap persentase kulit tercemar getah kuning. Aplikasi pupuk Ca dan B pada stadia 1 memiliki cemaran getah getah kuning paling rendah pada kulit buah yakni $32.15 \%$ dibandingkan dengan aplikasi pada saat antesis dan antesis + stadia 1 (Tabel 1). Hal ini menunjukkan bahwa waktu kritis kebutuhan $\mathrm{Ca}$ buah manggis terjadi pada stadia 1 yaitu pada fase pertumbuhan dan perkembangan buah.

Penurunan persentase kulit tercemar berkaitan dengan tersediannya hara $\mathrm{Ca}$ dalam tanah yang dapat diserap oleh tanaman. Tanaman yang tidak mendapatkan suplai $\mathrm{Ca}$ yang cukup mengalami kerusakan pada sel, termasuk pecahnya saluran getah kuning. Poerwanto et al. (2010) menyatakan pemberian $\mathrm{Ca}$ akan menjaga getah kuning tetap berada pada salurannya.

Cemaran getah kuning pada aril maupun kulit mengalami penurunan sebesar $28.46 \%$ pada aril dan $27.60 \%$ pada kulit akibat meningkatnya kandungan Ca dan B pada buah yang telah diberi dolomit dan finbor (Tabel 1). Marschner (1995) menyatakan Ca berperan sebagai perekat antar dinding sel dapat meningkatkan integritas antara sel-sel epitel penyusun sekretori saluran getah kuning pada buah manggis. $\mathrm{Ca}$ diserap dalam bentuk $\mathrm{Ca}^{2+}$ melalui aliran transpirasi dan intersepsi akar. Kekurangan $\mathrm{Ca}$ dapat mengakibatkan kerusakan pada tingkat sel seperti pecahnya saluran getah kuning yang akan menyebabkan cemaran getah kuning pada aril.

$\mathrm{Ca}$ merupakan salah satu unsur hara makro yang bersifat tidak mobil dalam tanaman, sehingga $\mathrm{Ca}$ harus diberikan pada saat yang tepat. Selama perkembangan buah manggis, kebutuhan $\mathrm{Ca}$ pada dinding sel mengalami peningkatan dan akan menurun menjelang pemasakan (Rigney dan Wills, 1981; Poovarodom, 2009). Perbedaan laju pembelahan dan pembesaran sel selama perkembangan buah akan mempengaruhi kebutuhan Ca sehingga akan berpengaruh pula terhadap serapannya pada setiap stadia perkembangan buah. Saat laju pembelahan dan pembesaran sel yang tinggi, maka buah akan menjadi sink yang kuat bagi nutrient termasuk Ca. Pada stadia 1 perkembangan buah manggis terjadi proses pembelahan yang membutuhkan $\mathrm{Ca}$ dalam jumlah yang besar untuk mengatur proses tersebut (Ashari, 2006). Pemberian Ca pada saat ini akan membuat penyerapannya ke buah lebih maksimal. Dear dan Weir (2004) menyatakan unsur $\mathrm{B}$ berperan dalam pembelahan dan pembesaran sel yang sedang berkembang. B diketahui memberikan pengaruh terhadap peningkatan kekuatan dinding sel dan ikatan antar sel (Harholt et al., 2010). Kebutuhan B yang tidak tercukupi pada tanaman menyebabkan tanaman sangat rentan mengalami kerusakan sel termasuk pecahnya saluran getah kuning. Menurut penelitian Martias (2012) bahwa peningkatan kosentrasi Ca dan B di kulit buah dapat menurunkan cemaran getah kuning.

\section{Kualitas Fisik Buah}

Aplikasi Ca dan B pada fase antesis, stadia 1 dan antesis + stadia 1 tidak memberikan pengaruh yang nyata terhadap diameter transversal dan diameter longitudinal buah manggis. Hasil penelitian menunjukkan buah manggis di Cikembar memiliki diameter yang paling besar. Diameter longitudinal buah manggis yang dihasilkan pada penelitian ini adalah antara 47-51 mm, sedangkan diameter transversalnya adalah 47-58 $\mathrm{mm}$ (Tabel 2). Lokasi penelitian berpengaruh nyata terhadap diameter transversal dan longitudinal buah manggis.

Salah satu penentu mutu buah manggis adalah warna dan kesegaran sepal buah. Warna dan kesegaran sepal mempengaruhi penilaian mutu selama penyimpanan. Buah manggis segar memiliki warna sepal yang hijau segar kemudian berubah menjadi coklat. Pada awal penyimpanan rata-rata sepal buah berwarna hijau kecoklatan dengan kesegaran sepal yang kurang segar. Pemberian pupuk $\mathrm{Ca}$ dan B pada saat antesis, stadia 1 dan antesis + stadia 1 tidak berpengaruh terhadap bobot buah dan bagian-bagiannya, namun lokasi penelitian berpengaruh nyata terhadap bobot buah dan bagian-bagian buah kecuali bagian cupat buah (Tabel 3). Bobot buah dan bagianbagiannya merupakan parameter untuk menghitung persentase buah yang dapat dimakan. Buah manggis yang diamati pada penelitian ini memiliki bobot antara 75-101 g. Buah manggis dengan bobot paling tinggi yaitu buah manggis Cikembar. Hal ini didukung oleh diameter buah manggis yang paling besar, namun berbanding terbalik dengan porsi dapat dimakan. Persentase porsi dapat dimakan buah manggis dari Cikembar (22\%) paling kecil jika dibandingkan buah 
manggis di Cigudeg dan Citeureup. Bila dibandingkan dengan porsi dapat dimakan buah pepaya $(75 \%)$, mangga $(65 \%)$ dan avokad (62\%), manggis memiliki porsi dapat dimakan yang kecil (Rai et al., 2006). Oleh karena itu, pencemaran getah kuning pada aril harus dikendalikan agar porsi dapat dimakan tersebut dapat dipertahankan. Menurut Daryono dan Sosrodiharjo (1986), sebagian besar buah manggis terdiri atas kulit sehingga nilai porsi buah manggis yang dapat dimakan rendah dan bahkan jauh lebih rendah dibandingkan buah-buah lain yang kebanyakan sekitar 60\%.
Kualitas fisik lain yang diamati adalah kekerasan dan ketebalan kulit buah. Terdapat kekhawatiran bahwa aplikasi $\mathrm{Ca}$ dapat menyebabkan kulit buah semakin keras yang disebabkan oleh meningkatnya ketegaran ikatan dinding sel karena ikatan pektin yang semakin kuat. Tabel 4 menunjukkan bahwa pemberian Ca dan B pada saat antesis, stadia 1 , antesis + stadia 1 tidak meningkatkan kekerasan kulit buah manggis. Tingkat kekerasan buah manggis berkisar antara 2.5 $3.4 \mathrm{~kg} \mathrm{dt}^{-1}$ menunjukkan bahwa kekerasan kulit buah normal, artinya buah masih dapat dibuka.

Tabel 2. Pengaruh lokasi, dosis Ca dan B dan waktu aplikasi terhadap diameter transversal dan longitudinal buah manggis.

\begin{tabular}{|c|c|c|}
\hline \multirow{2}{*}{ Perlakuan } & \multicolumn{2}{|c|}{ Diameter (mm) } \\
\hline & Longitudinal & Transversal \\
\hline \multicolumn{3}{|l|}{ Lokasi } \\
\hline Cigudeg & $49.64 \mathrm{a}$ & $53.73 b$ \\
\hline Citeureup & $47.07 \mathrm{~b}$ & $46.75 \mathrm{c}$ \\
\hline Cikembar & $51.26 \mathrm{a}$ & $58.24 \mathrm{a}$ \\
\hline \multicolumn{3}{|l|}{ Dosis $\mathrm{Ca}+\mathrm{B}$} \\
\hline 0 & 51.03 & 51.04 \\
\hline $1.6 \mathrm{~kg} \mathrm{Ca}+1.55 \mathrm{~kg} \mathrm{~B}$ pohon $^{-1}$ & 48.43 & 52.97 \\
\hline $3.2 \mathrm{~kg} \mathrm{Ca}+1.55 \mathrm{~kg} \mathrm{~B}$ pohon $^{-1}$ & 48.47 & 54.70 \\
\hline \multicolumn{3}{|l|}{ Waktu Aplikasi } \\
\hline Antesis & 49.47 & 53.19 \\
\hline Stadia 1 & 48.68 & 52.84 \\
\hline Antesis + Stadia 1 & 49.79 & 52.68 \\
\hline
\end{tabular}

Keterangan: Angka-angka yang diikuti huruf yang sama pada kolom yang sama, menunjukkan tidak berbeda nyata berdasarkan uji DMRT $\alpha=5 \%$.

Tabel 3. Pengaruh lokasi, dosis Ca dan B dan waktu aplikasi terhadap bobot buah, bagian-bagian buah dan porsi dapat dimakan buah manggis.

\begin{tabular}{lrrrrrr}
\hline \multirow{2}{*}{ Perlakuan } & \multicolumn{5}{c}{ Bobot (g) } & $\begin{array}{c}\text { Porsi Dapat } \\
\text { Dimakan } \\
\end{array}$ \\
\cline { 2 - 6 }$(\%)$
\end{tabular}

Keterangan: Angka-angka yang diikuti huruf yang sama pada kolom yang sama, menunjukkan tidak berbeda nyata berdasarkan uji DMRT $\alpha=5 \%$. 
Peningkatan kekerasan kulit buah manggis dapat terjadi karena hilangnya air dari kulit buah akibat transpirasi dan respirasi. Proses kehilangan air pada kulit buah tersebut menyebabkan kadar air kulit buah menjadi rendah. Ruang antar sel parenkim pada kulit buah yang awalnya terisi air menjadi kering sehingga ruang-ruang antar sel tersebut menyatu dan zat pektin yang terdapat pada dinding sel-sel parenkim saling berikatan. Ikatan pektin yang semakin kuat tersebut menyebabkan penebalan dinding sel.
Penebalan dinding sel inilah yang menyebabkan kulit buah menjadi keras. Kulit buah yang keras menyebabkan buah sulit dibuka. Peningkatan kandungan $\mathrm{Ca}$ pada kulit buah dapat menghambat laju respirasi buah, hal ini terjadi karena ikatan antara Ca dengan pektat pada dinding sel mengurangi permeabilitas air pada membran sel sehingga menghambat laju respirasi. Terhambatnya laju respirasi mengurangi kehilangan air buah, sehingga mencegah terjadinya pengerasan kulit buah (Qanytah, 2004).

Tabel 4. Pengaruh lokasi, dosis Ca dan B dan waktu aplikasi terhadap kekerasan dan ketebalan kulit buah manggis.

\begin{tabular}{lcc}
\hline \multicolumn{1}{c}{ Perlakuan } & $\begin{array}{c}\text { Kekerasan } \\
\left(\mathrm{kg} \mathrm{dt}^{-1}\right)\end{array}$ & $\begin{array}{c}\text { Tebal Kulit } \\
(\mathrm{mm})\end{array}$ \\
\hline Lokasi & & \\
$\quad$ Cigudeg & 3.27 & $2.02 \mathrm{c}$ \\
Citeureup & 3.00 & $6.34 \mathrm{~b}$ \\
Cikembar & 3.01 & $7.58 \mathrm{a}$ \\
\hline Dosis Ca+B & & \\
0 & 2.53 & $6.38 \mathrm{a}$ \\
$1.6 \mathrm{~kg} \mathrm{Ca}+1.55 \mathrm{~kg} \mathrm{~B}$ pohon $^{-1}$ & 3.53 & $4.57 \mathrm{~b}$ \\
$3.2 \mathrm{~kg} \mathrm{Ca}+1.55 \mathrm{~kg} \mathrm{~B}^{-1}$ & 3.23 & $4.97 \mathrm{~b}$ \\
\hline Waktu Aplikasi & & \\
Antesis & 2.92 & $4.63 \mathrm{~b}$ \\
Stadia 1 & 2.90 & $5.67 \mathrm{a}$ \\
Antesis + Stadia 1 & 3.47 & $5.63 \mathrm{a}$ \\
\hline
\end{tabular}

Keterangan: Angka-angka yang diikuti huruf yang sama pada kolom yang sama, menunjukkan tidak berbeda nyata berdasarkan uji DMRT $\alpha=5 \%$.

Tabel 5. Pengaruh lokasi, dosis Ca dan B dan waktu aplikasi terhadap PTT, ATT dan skor rasa buah manggis.

\begin{tabular}{llcc}
\hline \multicolumn{1}{c}{ Perlakuan } & $\begin{array}{c}\text { PTT } \\
\left({ }^{\circ} \text { Brix }\right)\end{array}$ & $\begin{array}{c}\text { ATT } \\
(\%)\end{array}$ & Skor Rasa Buah \\
\hline Lokasi & & & \\
$\quad$ Cigudeg & $18.32 \mathrm{a}$ & $0.45 \mathrm{~b}$ & 4.20 \\
Citeureup & $17.91 \mathrm{ab}$ & $0.52 \mathrm{~b}$ & 3.50 \\
Cikembar & $17.70 \mathrm{~b}$ & $0.88 \mathrm{a}$ & 3.90 \\
\hline Dosis Ca+B & & & \\
0 & 17.74 & 0.64 & 3.81 \\
1.6 kg Ca + 1.55 kg B pohon ${ }^{-1}$ & 18.15 & 0.61 & 3.88 \\
3.2 kg Ca + 1.55 kg B pohon ${ }^{-1}$ & 18.04 & 0.59 & 3.98 \\
\hline Waktu Aplikasi & & & \\
Antesis & 17.69 & 0.54 & 3.70 \\
Stadia 1 & 18.22 & 0.65 & 3.90 \\
Antesis + Stadia 1 & 18.03 & 0.65 & 4.10 \\
\hline
\end{tabular}

Keterangan: Angka-angka yang diikuti huruf yang sama pada kolom yang sama, menunjukkan tidak berbeda nyata berdasarkan uji DMRT $\alpha=5 \%$. PTT = padatan terlarut total. ATT $=$ asam tertitrasi total. 


\section{Kualitas Kimia Buah}

Tabel 5 menunjukkan lokasi penelitian berpengaruh nyata terhadap nilai PTT dan ATT buah manggis. Nilai PTT tertinggi yaitu di Cigudeg dengan rata-rata $18.32{ }^{\circ}$ Brix. Nilai PTT di Citeureup yaitu $17.91{ }^{\circ} \mathrm{Brix}$ dan di Cikembar dengan rata-rata $17.70{ }^{\circ} \mathrm{Brix}$, nilai ini sesuai dengan kisaran PTT menurut Kader (2006) yaitu $17-20{ }^{\circ}$ Brix. Hal ini menunjukkan bahwa buah manggis di Cigudeg lebih manis dibandingkan buah manggis di Citeureup dan Cikembar. Hasil ini ditunjang oleh nilai skoring buah manggis di Cigudeg yaitu 4.2 yang menunjukkan rasa manis.

Peningkatan PTT selama perkembangan buah manggis disebabkan adanya pemecahan senyawa kompleks menjadi lebih sederhana seperti karbohidrat menjadi sukrosa, glukosa dan fruktosa. Proses hidrolisis pati menjadi glukosa tersebut terjadi karena proses respirasi buah. Proses respirasi pada buah membutuhkan energi yang dihasilkan dari perombakan pati menjadi glukosa (Salisbury dan Ross, 1995).

Nilai ATT buah tertinggi yaitu di Cikembar dengan rata-rata $0.88 \%$, sedangkan nilai ATT buah manggis terendah di Cigudeg yaitu $0.45 \%$. Kandungan ATT buah akan semakin tinggi jika buah semakin tua. Kandungan asam pada buah manggis tidak dipengaruhi oleh kandungan kalsium buah. Perubahan kandungan asam pada buah manggis sama dengan pisang Tanduk, Raja Sere, Barangan, mangga Gedong dan Nenas Subang. Semakin tua buah manggis maka semakin tinggi kandungan asamnya (Suyanti et al., 1999). Penilaian rasa buah berdasarkan skoring menghasilkan skor rasa 3 (manis sedikit asam) sampai skor rasa 4 (manis). Pemupukan Ca dan B pada fase antesis, stadia 1 dan antesis + stadia 1 tidak memberikan pengaruh terhadap parameter padatan terlarut total (PTT), asam tertirasi total (ATT).

\section{KESIMPULAN}

Lokasi penelitian dengan kualitas buah manggis terbaik adalah Cikembar dengan persentase cemaran getah kuning pada aril sebesar $22.49 \%$ dan kulit sebesar $29.51 \%$. Dosis $1.6 \mathrm{~kg} \mathrm{Ca} \mathrm{pohon}^{-1}+1.55 \mathrm{~g} \mathrm{~B}^{-1}$ pohon $^{-1}$ dan $3.2 \mathrm{~kg} \mathrm{Ca}$ pohon $^{-1}+1.55 \mathrm{~g} \mathrm{~B}$ pohon $^{-1}$ sama baiknya dalam mengendalikan cemaran getah kuning pada buah manggis dengan tingkat cemaran terendah pada aril sebesar $19.91 \%$ dan pada kulit sebesar $28.86 \%$ dengan waktu aplikasi Ca dan B terbaik pada stadia 1 karena mampu menurunkan persentase cemaran getah kuning di aril sebesar $40.44 \%$ dan pada kulit sebesar 27.10\%. Pemberian pupuk Ca dan B tidak mempengaruhi kualitas fisikokimia yang mencakup diameter, bobot, kekerasan, padatan terlarut total dan asam tertitrasi total buah manggis di tiga lokasi penelitian.

\section{UCAPAN TERIMA KASIH}

Terima kasih diucapkan Program Hibah Kompetensi dengan Judul "Perbaikan Kualitas buah Manggis dan Mangga sebagai Upaya Peningkatan Ekspor Buah Tropika Nusantara" atas nama Prof. Dr. Ir. Roedhy Poerwanto, M.Sc., untuk tahun anggaran 2013.

\section{DAFTAR PUSTAKA}

Ashari, S. 2006. Hortikultura: Aspek Budidaya. Ed. rev. Jakarta: UI Pr. 342-344.

Bangerth, F. 1979. Calcium-related physiological disorders of plants. Ann. Rev. Phytopathol. 17: 97-122.

Blevins, D.G., K.M. Lukaszewski. 1998. Boron in plant structure and function. Annu. Rev. Plant Physiology. 49: 481-500.

[BPS] Badan Pusat Statistik. 2014. Statistik: Hortikultura. http://www.bps.go.id/ [diunduh 7 Februari 2015]

[BSN] Badan Standardisasi Nasional. 2009. Standar Nasional Indonesia (SNI) Manggis. Jakarta: Badan Standardisasi Nasional. SNI 3211:2009.

Daryono, M., Sosrodiharjo. 1986. Cara praktis penentuan saat pemanenan buah manggis dan sifat-sifatnya selama penyimpanan. Buletin Penelitian Hortikultura. 14: 39-42.

Dear, B.S., R.G. Weir. 2004. Boron deficiency in pastures and field crops. Agfact P1. AC.1, 2nd edition. 
Dorly, S., S. Tjitrosemito, R. Poerwanto, Juliarni. 2008. Secretory duct structure and phytochemistry coumpounds of yellow latex in mangosteen fruit. HAYATI J. Biosci. 15: 99-104.

Dorly, S. 2009. Studi struktur sekretori dan fitokimia getah kuning serta aplikasi kalsium untuk mengatasi getah kuning buah manggis (Garcinia mangostana L.). Disertasi. Sekolah Pascasarjana Institut Pertanian Bogor. Bogor. 134.

Harholt, J., A. Suttangkakul, H.V. Scheller. 2010. Biosynthesis of pectin. Plant Physiology. 153: 384-395.

Huang, X.M., H.C. Wang, J.G. Li, J.H. Yin, W.Q. Yuan, J.M. Lu, H.B. Huang. 2005. An overview of calcium's role in lychee fruit cracking. In: Chomchalow $\mathrm{N}$ and Sukhvibul N (eds.). Proceedings of the II $^{\text {nd }}$ International Symposium on Lychee, Longan, Rambutan, and Other Sapindaceae Plants. Chiang Mai, Thailand, Agt. 25-28, 2003. Belgium: Acta Hort. 665: 231-240.

Kader, A.A. 2006. Mangosteen facts, recommendations for maintaining postharvest quality. http://postharvest.ucdavis.edu. shtml. [20 Juli 2014].

Marschner, H. 1995. Mineral Nutrition of Higher Plants. $2^{\text {nd }}$ Edition. Academic Press. London.

Martias. 2012. Studi peranan lingkungan (sifat kimia dan fisika tanah serta cuaca) terhadap cemaran getah kuning buah manggis (Garcinia mangostana L). Disertasi. Sekolah Pascasarjana Institut Pertanian Bogor. Bogor. 151.

O’Neill, M.A., T. Ishii, P. Albersheim, A.G. Darvill. 2004. Rhamnogalacturonan II: structure and function of a borate crosslinked cell wall pectic polysaccharide. Annu. Rev. Plant. Biol. 55: 109-139.

Pechkeo, S., S. Sdoodee, C. Nilnond. 2007. The effects of calcium and boron sprays on the incidence of translucent flesh disorder and gamboge disorder in mangosteen (Garcinia mangostana L.). Kasetsart. J. Nat. Sci. 41: 621-632.

[PKBT] Pusat Kajian Buah Tropika. 2007. Standar operasional prosedur manggis (Garcinia mangostana L.). Pusat Kajian Buah-buahan Tropika, LPPM-IPB. Bogor.

Poerwanto, R., Dorly, M. Martias. 2010. Getah kuning pada buah manggis dalam reorientasi riset untuk mengoptimalkan produksi dan rantai nilai hortikultura. hal. 255-260. Prosiding Seminar Nasional Hortikultura, 25-26 Januari 2010. Perhimpunan Hortikultura Indonesia. Denpasar, Bali.

Poovarodom, S. 2009. Growth and Nutrient Uptake into mangosteen (Garcinia mangostana L.) fruit. Proceedings of the International Plant Nutrition Colloquium XVI; UC Davis, 15 April 2009. UC Davis: Department of Plant Science. [terhubung berkala]. http:// www.escholarship.org/ [06 Juni 2015].

Poovarodom, S. 2010. Calcium and physiological disorders of mangosteen fruits. Proceedings of the $16^{\text {th }}$ Asian Agriculture Symposium and $1^{\text {st }}$ International Symposium on Agricultural Technology. Bangkok, Thailand. 25-27 August. 2010.

Primilestari, S. 2011. Pengendalian getah kuning dan peningkatan kualitas buah manggis melalui aplikasi kalsium dengan sumber dan dosis berbeda. Tesis. Sekolah Pascasarjana Institut Pertanian Bogor. Bogor. 51.

Purnama, T. 2014. Pemberian kalsium dan boron untuk pengendalian cemaran getah kuning pada buah manggis (Garcinia mangostana L.). Tesis. Sekolah Pascasarjana Institut Pertanian Bogor. Bogor. 38.

Qanytah. 2004. Kajian perubahan mutu buah manggis (Garcinia mangostana L.) dengan perlakuan precooling dan penggunaan giberelin selama penyimpanan. Tesis. Sekolah Pascasarjana Institut Pertanian Bogor. Bogor. 94. 
Rai, I.N., R. Poerwanto, L.K. Darusman, B.S. Purwoko. 2006. Perubahan kandungan giberelin dan gula total pada fase-fase perkembangan bunga manggis. Hayati. 13: 101-106.

Rigney, C.J., R.B.H. Wills. 1981. Calcium movement, a regulating factor in the initiation of tomato fruit ripening. HortScience. 16(4): 550-551.

Salisbury, F.B., C.W. Ross. 1995. Fisiologi Tumbuhan. Jilid Satu. Ed ke-4. D.R. Lukman, Sumaryono, penerjemah: Bandung (ITB) Pr. Terjemahan dari Plant Physiology. 145-146.

Saribu, D.S. 2011. Studi aplikasi kalsium dan boron terhadap pengendalian getah kuning pada buah manggis (Garcinia mangostana L.). Tesis. Sekolah Pascasarjana Institut Pertanian Bogor. Bogor. 44.
Susi, O. 2011. Studi waktu aplikasi kalsium terhadap pengendalian getah kuning dan kualitas buah manggis (Garcinia mangostana L.). Tesis. Sekolah Pascasarjana Institut Pertanian Bogor. Bogor. 50 hal.

Suyanti, Roosmani, D. Sastra. 1999 Karakteristik mutu buah manggis segar. J. Hort. 8(4): 1284-1292.

Saure, M.C. 2005. Calcium translocation to fleshy fruit: its mechanism and endogenous control. HortScience. 105: 6589.

Wulandari, I., r. Poerwanto. 2010. Pengaruh aplikasi kalsium terhadap getah kuning pada manggis (Garnicia mangostana L.). J. Hort. Indonesia. 1(1): 27-31. 